\title{
APRENDIZAGEM BASEADA EM PROBLEMAS PARA OS CURSOS DE CIÊNCIAS CONTÁBEIS: DESAFIOS E OPORTUNIDADES DE SUA ADOÇÃO
}

\author{
PROBLEM-BASED LEARNING FOR UNDERGRADUATE IN \\ ACCOUNTING: CHALLENGES AND OPPORTUNITIES OF ITS \\ ADOPTION
}

\section{APRENDIZAJE BASADO EN PROBLEMAS PARA LOS CURSOS DE CIENCIAS CONTABLES: DESAFÍOS Y OPORTUNIDADES DE SU ADOPCIÓN}

Sandro Vieira Soares

Doutor em Controladoria e Contabilidade Universidade de São Paulo, São Paulo, Brasil Professor do Programa de Pós-Graduação em Administração - Universidade do Sul de Santa Catarina, Florianópolis, Brasil

Professor do Curso de Ciências Contábeis -

Centro Universitário Municipal de São José, São

José, Brasil

sandrovs@usp.br

\section{Christopher Bulaon}

Mestre em Controladoria e Contabilidade Universidade de São Paulo, São Paulo, Brasil Analista - DoubleLine, Los Angeles, EUA chrisbulaon@gmail.com

\section{Silvia Pereira de Castro Casa Nova}

Pós-doutora pela University of Minnesota e pela Fundação Getúlio Vargas

Doutora em Controladoria e Contabilidade Universidade de São Paulo, São Paulo, Brasil Professora Titular no Departamento de Contabilidade e Atuária na Faculdade de Economia, Administração e Contabilidade Universidade de São Paulo, São Paulo, Brasil silvianova@usp.br

\section{Icaro Roberto Azevedo Picolli}

Mestre em Administração - Universidade do Sul de Santa Catarina, Florianópolis, Brasil

Professor - Serviço Nacional de Aprendizagem

Comercial, Florianópolis, Brasil

icaropicolli@gmail.com

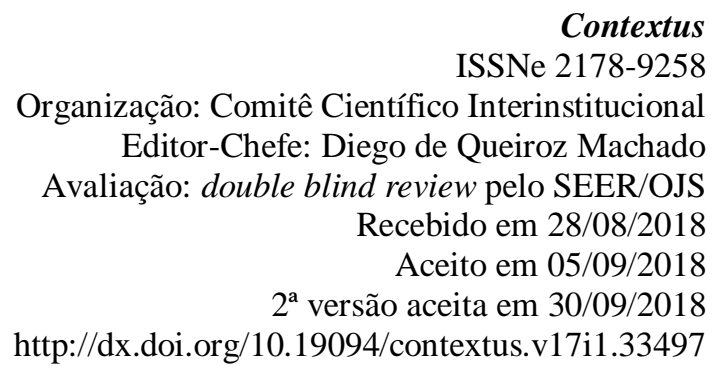

Contextus

SSNe 2178-9258

ação: Comitê Científico Interinstitucional Editor-Chefe: Diego de Queiroz Machado Aceito em $05 / 09 / 2018$ $2^{\mathrm{a}}$ versão aceita em 30/09/2018 http://dx.doi.org/10.19094/contextus.v17i1.33497

\section{RESUMO}

O objetivo deste trabalho é compreender as dificuldades e vantagens encontradas por docentes em Ciências Contábeis que vivenciaram a adoção do problem-based learning. Para atingir esse objetivo, desenvolveu-se uma pesquisa qualitativa, com entrevistas com especialistas. A análise das entrevistas foi realizada por meio da análise de conteúdo. Os achados mostraram que as principais dificuldades de adoção do PBL decorrem de 


\title{
APRENDIZAGEM BASEADA EM PROBLEMAS PARA OS CURSOS DE CIÊNCIAS CONTÁBEIS: DESAFIOS E OPORTUNIDADES DE SUA ADOÇÃO
}

fatores que envolvem desde a formação e experiência prévia dos estudantes até a demanda de trabalho extra por parte do decente, oriunda do tempo que dedica para planejar as aulas e preparar materiais didáticos. Por outro lado, os benefícios relatados englobam o desenvolvimento de habilidades para realização de pesquisa, trabalho em equipe, assunção de responsabilidades quanto ao próprio aprendizado, bem como exposição ao ambiente do mercado. A pesquisa concluiu que a adoção do PBL traz benefícios para os estudantes e promove um alinhamento entre a formação acadêmica e as demandas do mercado.

Palavras-chave: aprendizagem baseada em problemas; PBL; educação contábil; ensino superior; metodologias ativas.

\begin{abstract}
The goal of this study is to understand difficulties and advantages faced by accounting faculty staff who adopted PBL in the classroom. To attain this goal, we developed a qualitative research based on interviews with specialists. The findings showed the main difficulties arise from many factors since students' educational background and previous experience up to extra time and effort demanded from teachers to plan the class and to prepare instructional materials. On the other hand, reported benefits include the development of research skills, teamwork, responsibility taking with respect to self-learning, and exposure to a simulated work environment. We concluded that the adoption of PBL brings benefits to students and promotes an alignment between academic education and professional market demands.
\end{abstract}

Keywords: problem-based learning; PBL; accounting education; higher education; active learning methods.

\section{RESUMEN}

El objetivo de este estudio es comprender las dificultades y ventajas encontradas por los docentes en ciencias contables que vivieron la adopción del problem-based learning (PBL) en el salón de clases. Para alcanzar este objetivo, fue desarrollado un estudio cualitativo, con entrevistas con especialistas. El análisis de las entrevistas fue realizado por medio del análisis del contenido. Los hallazgos muestran que las principales dificultades de adopción del PBL tienen origen en factores desde la formación y experiencia previa de los estudiantes hasta las dificultades oriundas del trabajo extra demandado del docente para la planificación de las clases y preparación de materiales didácticos. Los beneficios relatados comprenden el desarrollo de habilidades para la realización del estudio, trabajo en equipo, asunción de responsabilidades en cuanto al propio aprendizaje, así como exposición al ambiente del mercado. El estudio concluyó que la adopción del PBL trae beneficios para los estudiantes y promueve un alineamiento entre la formación académica y las demandas del mercado.

Palabras clave: aprendizaje basado en problemas; PBL; educación contable; enseñanza superior; metodologías activas.

\section{INTRODUÇÃO}

A busca por metodologias de aprendizagem que constituam uma alternativa às tradicionais aulas expositivas ganhou força, em anos recentes, devido a alterações no perfil de estudantes que vêm ingressando no ensino superior. Nesse sentido, as discussões sobre metodologias ativas de aprendizagem têm ocupado cada vez mais espaço no ambiente acadêmico (LEAL; MIRANDA; CASA NOVA, 2017; BACICH; MORAN, 2018; VENDRAMIN et al., 2018).

Dentre as opções de metodologias ativas de aprendizagem, esta pesquisa investigou o caso do problem-based learning (PBL), uma metodologia pedagógica, baseada no construtivismo, na qual problemas reais são usados em conjunto com um ambiente de aprendizagem em que estão incorporadas atividades de investigação, aprendizagem autodirecionada, extração de informação, diálogo e solução colaborativa de problemas (TAN, 2004). 
Stanley e Marsden (2012) indicam que o PBL surgiu na área de educação médica, no Canadá e Estados Unidos, nas décadas de 1950 e 1960. Segundo os autores, atualmente, adotou-se o PBL, com sucesso, nas áreas de enfermagem, engenharia, serviço social, direito, administração de empresas e economia. O uso do PBL, no Brasil, nos cursos de Ciências Contábeis, já foi relatado pelas pesquisas de Siqueira et al. (2009), Frezatti e Silva (2014), Martins, Espejo e Frezatti (2015), Frezatti et al. (2016) e Vendramin et al. (2018); e, no curso de Administração, pelas pesquisas de Escrivão Filho e Ribeiro (2008), Silva, Oliveira e Motta (2013), Pádua Jr. et al. (2014) e Souza e Verdinelli (2014).

No entanto, adotar uma metodologia de ensino-aprendizagem não tradicional demanda que os professores, às vezes, nunca antes expostos a metodologias distintas da aula expositiva em sua formação acadêmica, passem por um processo de adaptação. Diante desse contexto, apresenta-se a seguinte questão de pesquisa: quais são os desafios e oportunidades encontrados por docentes de Ciências Contábeis em decorrência da utilização do PBL? Assim, o objetivo desta pesquisa é compreender as dificuldades e vantagens encontradas pelos docentes que vivenciaram a adoção do PBL em sala de aula.

Esta pesquisa se justifica pela possibilidade de identificar as dificuldades que docentes de Ciências Contábeis podem encontrar quando decidem utilizar o PBL como metodologia de ensino, além de identificar as formas utilizadas para contornar essas dificuldades por docentes que já vivenciaram a adoção do PBL. Ressalta-se, ainda, que a adoção de metodologias de aprendizagem ativas se faz oportuna, à medida que os currículos de cursos da área de negócios estão priorizando a promoção do know why, em detrimento do know how (MARION; MARION, 2006).

\section{REVISÃO DE LITERATURA}

Pesquisas sobre a implementação do PBL na área da educação contábil têm recebido mais atenção nas últimas décadas. Como o papel dos contabilistas está evoluindo juntamente com a tecnologia, o mercado está demandando melhorias no ensino de Contabilidade.

Johnstone e Biggs (1998) propõem várias estratégias para implementar a PBL em disciplinas de graduação, argumentando que a inclusão de recursos PBL em todo o currículo incentiva o encapsulamento do conhecimento. Isso, em última análise, auxilia no desenvolvimento da especialização contábil. Nesse sentido, identificaram quatro principais 
características do PBL: o conhecimento técnico básico, ensinado no contexto de casos realistas; as competências gerais de resolução de problemas, que são especificamente ensinadas; a ênfase em pequenos grupos; e a aprendizagem centrada no aluno. Esses mesmos autores enfatizam que o PBL é mais bem implementado somente depois de os estudantes possuírem um conhecimento básico de Contabilidade, salientando ainda a importância do auxílio de tutores com experiência na área. Devido à natureza variada de implementação do PBL, é importante que cada instituição identifique e esclareça seus objetivos de aprendizagem e padrões de implementação.

Cottell (2010), em seu estudo, descreve sua experiência com o problema das Lojas Shreffler. Tal problema, amplo e não estruturado, se desdobra em níveis, e os alunos recebem mais informações em fases posteriores, cada uma com diferentes objetivos de aprendizagem. Ao final, a opinião dos estudantes sobre o uso do PBL foi uma "experiência agradável e significativa" (COTTELL, 2010, p. 785).

Lehmann (2010) também apresenta uma série de casos abertos e não estruturados no contexto dos sistemas de auditoria e de controle interno. De modo semelhante, os casos são suficientemente curtos para cobrir os objetivos de aprendizagem específicos e, muitas vezes, são aplicados em ambientes de pequenos grupos, ao longo do curso. Em contraste com a estratégia de Johnstone e Biggs (1998), Lehmann considera que os casos são mais eficazes quando implementados antes da parte expositiva da aula, como uma forma de criar pequenas provocações para estimular o interesse nos temas a serem discutidos. Observou-se que a reação dos estudantes a esses casos, geralmente, apresentou-se positiva, sendo percebidas como experiências agradáveis de trabalho em equipe e oportunidades de entender o livro didático.

O estudo de Dee e Durtschi (2010) focou na detecção de fraude no currículo de auditoria, por meio de uma equipe fictícia de beisebol, chamada Tallahassee BeanCounters (TBC). Várias características do caso-problema TBC o diferenciam dos casos antes mencionados. Os casos TBC foram implementados em um ambiente competitivo, em que as equipes foram incentivadas a competir diretamente. Além disso, o contexto de detecção de fraude do caso $\mathrm{TBC}$ envolveu o desenvolvimento ativo de habilidades de interrogatório de suspeitos ao vivo, em vez de coleta de dados. Os autores discutiram várias estratégias para gerenciar a carga de trabalho do professor, como limitar a quantidade de tempo trabalhado pelos alunos em cada caso, designar um estudante de pós-graduação para responder a perguntas e penalizar a pontuação de uma equipe se esta faz perguntas em excesso. Inclusive, 
o caso-problema TBC tem sido utilizado em nove universidades dos EUA, e o feedback geral dos alunos é julgá-lo uma experiência muito positiva e de aprendizagem gratificante. Semelhante aos trabalhos de pesquisa anteriores, os resultados indicaram que os estudantes, realmente, apreciam o engajamento ativo e desenvolvimento de uma variedade de habilidades.

Stanley e Marsden (2012; 2013) exploraram as percepções dos alunos sobre sua experiência com PBL, num estudo com sete cortes diferentes de estudantes de graduação em Contabilidade, do último ano, na Queensland University of Technology (QUT), na Austrália. Os dados, quantitativos e qualitativos, obtidos ao longo de quatro anos indicaram uma implementação bem-sucedida de PBL, no currículo de Contabilidade. Os resultados indicaram, ainda, que PBL geralmente é eficaz no desenvolvimento das áreas de interrogatório, trabalho em equipe e solução de problemas.

Embora o uso do PBL seja fato conhecido em cursos de Contabilidade estrangeiros, como mostram as pesquisas anteriormente citadas, no Brasil, faz-se necessário um relato mais detalhado sobre o PBL, em decorrência das características histórico-normativas dos cursos como as apresentadas por Peleias et al. (2007) e Soares et al. (2011).

Rodrigues e Araujo (2007) objetivaram identificar se o método PBL é aplicável nas disciplinas de Contabilidade. Conforme as autoras identificaram, os alunos percebem o PBL, de modo geral, como uma oportunidade de variar a rotina das aulas, de explorar os recursos disponibilizados pela instituição e de se sentirem livres para decidir a respeito das atividades desenvolvidas em sala, dentro de um processo de autoaprendizagem. E afirmam, ainda, que a maioria dos alunos apreciou a dinâmica do método PBL, expressando, espontaneamente, satisfação ao docente em várias ocasiões. No entanto, tal satisfação geral não impediu a resistência ao método, como da aluna que chegou a perguntar "quando o docente daria aula" (RODRIGUES; ARAUJO, 2007).

Lobosco (2007) comparou o PBL com o aprendizado tradicional, em três turmas de duas instituições de ensino, por meio de uma pesquisa conduzida em duas etapas: uma survey e um experimento. Na conclusão da autora, os estudantes entendiam a aula tradicional como um processo de ensino que não lhes permitia transpor o conhecimento adquirido para uma situação da vida real, não concordando como aprendizagem efetiva a realização de exercícios repetitivos e reconhecendo como mais agradável uma aula com situações envolvendo o estudo do texto e a resolução de problemas reais. De fato, dos alunos ingressantes no curso de Ciências Contábeis, em 2006 e 2007, com quem a pesquisa de Lobosco foi realizada, 
aproximadamente $60 \%$ tinham entre 18 e 33 anos, de modo que nasceram nas décadas de 1970 e 1980, sendo, portanto, pertencentes à chamada geração Y, também conhecida como geração do milênio ou geração da Internet. A sociologia indica que uma das características dessa geração é a necessidade desses de se sentirem constantemente desafiados; e uma das características do PBL apresentar características mais desafiadoras aos estudantes que o método tradicional de aula expositiva.

No estudo de Vasconcelos et al. (2007), há uma discussão teórica sobre o quanto metodologias de aprendizagem colaborativa, com foco em problemas, pode contribuir para o desenvolvimento do perfil de profissional contador buscado atualmente pelo mercado. Os autores afirmam que, em decorrência das mudanças do mercado, as empresas tenderão a demandar profissionais mais dinâmicos, adaptados ao trabalho em equipe, e que a aprendizagem colaborativa pode, sim, preparar melhor o contador para atender a essa demanda.

Soares e Araújo (2008) realizaram uma pesquisa, utilizando diversas ferramentas e técnicas de análise junto a 40 estudantes de Ciências Contábeis. Segundo os resultados da análise quantitativa, a exposição ao PBL permitiu aos alunos ganhar mais conhecimento na área, adquirir capacidade para resolução de problemas, melhorar habilidades de comunicação, desenvolver habilidades em geral, além de se tornarem mais confiantes. Já os resultados da análise qualitativa mostraram que houve reações negativas ao método por parte dos alunos, como exemplifica o trecho: "Alguns gostaram do método prático, já eu prefiro a explicação da professora com seus slides e aulas expositivas (Respondente 29)" (SOARES; ARAÚJO, 2008, p. 13).

Conforme estudo de Siqueira et al. (2009), desenvolvido em uma universidade federal, há ganhos na habilidade de comunicação, pesquisa, competitividade e até controle da timidez. Por outro lado, os alunos mostraram acreditar que pode haver uma aprendizagem incompleta do conteúdo da matéria e que o método pode não ser aplicável a todas as disciplinas. Segundo um dos alunos, o método é aplicável "em alguma parte sim. Eu não consigo visualizar uma matemática financeira naquele método. Mas na área gerencial com certeza” (SIQUEIRA et al., 2009, p. 112).

Benjamim Jr. (2011) desenvolveu um quase experimento, cujos resultados mostraram que os alunos, expostos ao PBL, percebem maior ganho de autonomia, de aprendizagem e de habilidade de solução de problemas do que os alunos expostos às tradicionais aulas 
expositivas. No entanto, segundo indica o autor, o PBL não deve ser considerado substituto de metodologias tradicionais, mas sim um poderoso complemento.

Frezatti e Silva (2014) desenvolveram uma pesquisa, cujo objetivo era identificar como manter/tiver o interesse do estudante frente ao desafio da tensão prática versus incerteza em disciplinas na área de negócios, que adotam o PBL. Os autores identificaram fatoreschave, acerca do planejamento e da condução da disciplina, com impacto direto sobre o sucesso da adoção do PBL, como a definição do líder das equipes, a definição clara do papel desempenhado pelos demais membros, as formas de acesso e estímulo de uso da literatura, a complementação com aulas expositivas e o feedback dado com regularidade aos estudantes.

Martins, Espejo e Frezatti (2015) desenvolveram um estudo de caso, baseado em uma disciplina de contabilidade gerencial, com o intuito de relatar a operacionalização da adoção do PBL na disciplina, bem como identificar as possíveis vantagens dessa adoção. Os resultados da pesquisa mostraram que os alunos desenvolveram mais as capacidades de resolver problemas de ordem prática e de desenvolver pesquisas, assim como os professores são expostos a um ambiente contextualizado que proporciona atualizar conceitos e teorias.

Frezatti et al. (2016) analisaram os elementos da sinergia dos Conhecimentos, Habilidades e Atitudes (CHA) na composição da nota de alunos de uma disciplina que adota o PBL. Na conclusão do estudo, o aluno - cujo primeiro contato com o PBL costuma se dar nessa disciplina - não tem a capacidade de discernir as razões pelas quais obteve nota de aprovação e conclui que o feedback contínuo é vital no decorrer da disciplina.

O estudo de Vendramin et al. (2018) buscou apresentar a percepção docente sobre a utilização do problem-based learning (PBL) em cursos de Contabilidade. Foi adotada uma abordagem qualitativa de pesquisa, com a condução de entrevistas semiestruturadas com quatro docentes, selecionandos, observando os seguintes critérios: estarem inseridos em curso de Ciências Contábeis, e terem utilizado a estratégia PBL. O estudo indicou uma falha na formação pedagógica dos docentes, com os entrevistados sendo unânimes ao dizerem haver obtido conhecimento do PBL somente após começarem a atuar como docentes, o que justifica a divergência de opiniões sobre o papel deles, algo capaz, segundo os autores, de colocar em risco os benefícios da utilização do método.

Por essas pesquisas citadas, fica evidente que, no Brasil, o interesse pela adoção do PBL é crescente em anos recentes. Os estudos convergem no sentido de o PBL proporcionar ao estudante de Ciências Contábeis a atuação num ambiente que simula o mercado de 


\section{APRENDIZAGEM BASEADA EM PROBLEMAS PARA OS CURSOS DE CIÊNCIAS CONTÁBEIS: DESAFIOS E OPORTUNIDADES DE SUA ADOÇÃO}

trabalho, possibilitando desenvolver habilidades de pesquisa, trabalhar em grupo, assumir papéis dentro das organizações e buscar respostas a problemas práticos e desestruturados.

\section{PROCEDIMENTOS METODOLÓGICOS}

O presente estudo se caracteriza como pesquisa exploratória, com abordagem qualitativa na forma de entrevistas semiestruturadas, realizada junto a especialistas, pesquisadores e professores, escolhidos, intencionalmente, em razão de sua experiência de pesquisa sobre aprendizagem baseada em problemas ou de sua experiência com a adoção deste método de ensino em sala de aula.

“As pesquisas exploratórias têm como propósito proporcionar maior familiaridade com o problema, com vistas a torná-lo mais explícito [...] Seu planejamento tende a ser bastante flexível, pois interessa considerar os mais variados aspectos relativos ao fato ou fenômeno estudado" (GIL, 2016, p. 27). Segundo Flick (2009), em contraste com as entrevistas biográficas, as entrevistas com especialistas têm menor interesse no entrevistado como pessoa do que em sua capacidade de ser um especialista num determinado campo de atividade.

O roteiro de entrevistas utilizado foi desenvolvido com base na literatura revisada e na experiência vivenciada pelos autores, sendo composto por oito questões, conforme mostra o Quadro 1.

Quadro 1 - Roteiro da entrevista

\begin{tabular}{|l|l|}
\hline \multicolumn{1}{|c|}{ Questão } & \multicolumn{1}{c|}{ Origem da questão } \\
\hline $\begin{array}{l}\text { 1. De onde surgiu o interesse por } \\
\text { PBL? (contato, formação) }\end{array}$ & $\begin{array}{l}\text { Os currículos dos cursos de bacharelado em Ciências Contábeis ou } \\
\text { Administração não contemplam conteúdos de formação pedagógica e } \\
\text { mesmo assim docentes optaram por adotá-lo. }\end{array}$ \\
\hline $\begin{array}{l}\text { 2. Por que estudar PBL em } \\
\text { Contabilidade? }\end{array}$ & $\begin{array}{l}\text { Escrivão Filho e Ribeiro (2008) tratam do uso de PBL no curso de } \\
\text { Administração e Siqueira et al. (2009) que discutem o que os médicos } \\
\text { podem ensinar aos contadores. }\end{array}$ \\
\hline $\begin{array}{l}\text { 3. Quais as maiores dificuldades de } \\
\text { implementação (dos alunos, da } \\
\text { instituição)? }\end{array}$ & $\begin{array}{l}\text { Rodrigues e Araújo (2007), Soares e Araújo (2008) e Krüger e Ensslin } \\
\text { (2013) investigaram, dentre outras coisas, a relação dos discentes com } \\
\text { metodologias ativas e o PBL. }\end{array}$ \\
\hline $\begin{array}{l}\text { 4. Do ponto de visto do professor, } \\
\text { quais são as principais demandas } \\
\text { para quem adota PBL? }\end{array}$ & $\begin{array}{l}\text { Bosi (2007) e Guimarães, Soares e Casagrande (2012) investigaram, } \\
\text { dentre outras coisas, as condições e motivações de trabalho de } \\
\text { professores. }\end{array}$ \\
\hline $\begin{array}{l}\text { 5. O PBL tem melhor adequação a } \\
\text { conteúdos genéricos ou } \\
\text { especializados? }\end{array}$ & $\begin{array}{l}\text { Siqueira et al. (2009) afirmam que o PBL é inadequado a alguns tipos de } \\
\text { conteúdo e Capacchi et al. (2007), Soares et al. (2012) e Galdino e Soares } \\
\text { 6. O PBL tem melhor adequação a } \\
\text { ciências humanas ou exatas? }\end{array}$
\end{tabular}

(CONTINUA) 


\section{(CONTINUAÇÃO)}

7. Houve problemas específicos na aplicação do PBL em

Contabilidade?

8. Qual é a sua expectativa no longo prazo (em termos de PBL em

Contabilidade)?

Fonte: elaboração própria.

As questões eram abertas para permitir que os entrevistados falassem livremente, expressando suas opiniões. A questão número 8, quando colocada para o entrevistado, foi acrescida de um complemento, dividindo a visão do entrevistado no curto e no longo prazo. Coube ao entrevistador incentivar que os entrevistados detalhassem e desenvolvessem melhor suas respostas, por meio de questões complementares, surgidas durante a interação da entrevista. O Quadro 2, por sua vez, sintetiza as características das entrevistas e dos entrevistados.

Quadro 2 - Descrição dos entrevistados e entrevistas

\begin{tabular}{|c|c|c|}
\hline Entrevistado & $\begin{array}{l}\text { Entrevista } \\
\end{array}$ & Caracterização \\
\hline $\begin{array}{l}\text { Entrevistada 1, } \\
\text { PhD., Professora } \\
\text { universitária. }\end{array}$ & $\begin{array}{l}\text { Entrevista realizada presencialmente, em São } \\
\text { Paulo, em } 4 \text { de dezembro de } 2013 \text {, com duração } \\
\text { de } 63 \text { minutos, transcrição em } 12 \text { páginas, em } \\
\text { inglês. }\end{array}$ & $\begin{array}{l}\text { Docente que utiliza o PBL em sala de } \\
\text { aula e desenvolveu pesquisa sobre o } \\
\text { tema. }\end{array}$ \\
\hline $\begin{array}{l}\text { Entrevistado } 2, \\
\text { Dr., Professor } \\
\text { universitário. }\end{array}$ & $\begin{array}{l}\text { Entrevista realizada a distância, via Skype }{ }^{\circledR} \text {, } \\
\text { em } 16 \text { de dezembro de } 2013 \text {, com duração de } \\
68 \text { minutos, transcrição em } 19 \text { páginas, em } \\
\text { português. }\end{array}$ & $\begin{array}{l}\text { Docente que utiliza o PBL em sala de } \\
\text { aula, desenvolveu pesquisa e é autor de } \\
\text { livro sobre o tema. }\end{array}$ \\
\hline $\begin{array}{l}\text { Entrevistado 3, } \\
\text { Dr., Professor } \\
\text { universitário. }\end{array}$ & $\begin{array}{l}\text { Entrevista realizada presencialmente, em São } \\
\text { Paulo, em } 19 \text { de março de } 2014 \text {, com duração } \\
\text { de } 45 \text { minutos, transcrição em } 15 \text { páginas, em } \\
\text { português. }\end{array}$ & $\begin{array}{l}\text { Docente que utiliza o PBL em sala de } \\
\text { aula e desenvolveu pesquisa sobre o } \\
\text { tema. }\end{array}$ \\
\hline $\begin{array}{l}\text { Entrevistada 4, } \\
\text { MSc., Professora } \\
\text { universitária. }\end{array}$ & $\begin{array}{l}\text { Entrevista realizada a distância, via Skype®, } \\
\text { em } 2 \text { de abril de } 2014 \text {, com duração de } 57 \\
\text { minutos, transcrição em } 23 \text { páginas, em } \\
\text { português. }\end{array}$ & $\begin{array}{l}\text { Docente que utiliza o PBL em sala de } \\
\text { aula, desenvolveu pesquisa e é autora } \\
\text { de livro sobre o tema. }\end{array}$ \\
\hline $\begin{array}{l}\text { Entrevistado 5, } \\
\text { MSc., Professor } \\
\text { universitário. }\end{array}$ & $\begin{array}{l}\text { Entrevista realizada presencialmente, em São } \\
\text { Paulo, em } 7 \text { de abril de 2014, com duração de } \\
23 \text { minutos, transcrição em } 7 \text { páginas, em } \\
\text { português. }\end{array}$ & $\begin{array}{l}\text { Docente que utiliza o PBL em sala de } \\
\text { aula e desenvolveu pesquisa sobre o } \\
\text { tema. }\end{array}$ \\
\hline $\begin{array}{l}\text { Entrevistada 6, } \\
\text { Dra., Professora } \\
\text { universitária. }\end{array}$ & $\begin{array}{l}\text { Entrevista realizada a distância, via Skype, em } \\
8 \text { de abril de } 2014 \text {, com duração de } 55 \text { minutos, } \\
\text { transcrição em } 19 \text { páginas, em português. }\end{array}$ & $\begin{array}{l}\text { Docente que utiliza o PBL em sala de } \\
\text { aula e desenvolveu pesquisa sobre o } \\
\text { tema. }\end{array}$ \\
\hline
\end{tabular}
Fonte: elaboração própria.

O grupo inicial de possíveis entrevistados era, numericamente, muito pequeno, considerando os critérios de recrutamento. A identificação dos possíveis entrevistados deu-se por meio da realização de uma pesquisa bibliométrica, na base de dados Spell, e em consulta ao Google Scholar. Os autores mais recorrentes dos artigos sobre PBL, encontrados nessa busca, formaram o grupo inicial. 
Assim, inicialmente, as entrevistas foram realizadas apenas com os entrevistados 1 e 2, que também indicaram possíveis entrevistados, alguns dos quais já haviam sido localizados na busca da Spell e Google Scholar. Essas entrevistas foram feitas, também, com o objetivo de se ter/tiver um piloto e verificar a adequação do roteiro. Por fim, elas foram transcritas e analisadas. A análise gerada a partir do conteúdo das duas primeiras entrevistas foi considerada relevante, de modo que o roteiro de entrevista não foi alterado, sendo, então, posteriormente, aplicado aos demais quatro entrevistados. Considerando a adequação do roteiro, a relevância do conteúdo e a raridade de especialistas para compor o grupo de informantes, optou-se por integrar as duas primeiras entrevistas ao corpus de análise.

A análise qualitativa dos dados foi desenvolvida conforme o método de análise de conteúdo proposto por Bardin (2016). Assim, as etapas da análise de conteúdo compreenderam: i. exploração inicial do material coletado, incluindo a preparação da análise; ii. leitura e codificação das entrevistas com a identificação das unidades de registro; e iii. interpretação dos dados coletados e descrição dos resultados.

$\mathrm{Na}$ pré-análise, inicialmente todas as entrevistas gravadas em arquivos em aparelhos celulares em formato Adaptive Multi-Rate (. a mr) foram convertidas em formato MPEG-1/2 Audio Layer 3 (. m p3) com o auxílio do serviço virtual Convertio. As entrevistas em formato. $\mathrm{m}$ p3 foram ouvidas e transcritas em texto na íntegra usando a ferramenta Bloco do Notas da Microsoft Windows ${ }^{\circledR}$ com auxílio do serviço virtual Google Speech®. Os documentos foram então convertidos para o editor de textos Word®, onde passaram por edição gramatical e separou-se as falas dos entrevistadores das falas dos entrevistados. Definiu-se nesta etapa que os índices seriam as frases que respondiam diretamente às perguntas efetuadas. Procedeu-se então a leitura flutuante das entrevistas transcritas encerrando com isto a etapa de pré-análise.

A etapa de codificação iniciou com a leitura exaustiva das entrevistas transcritas por, no mínimo, dois dos autores da presente pesquisa. As entrevistas foram então subdividas em trechos e cada trecho foi classificado em um tema. Esta classificação levou em conta a presença de palavras específicas, ligadas diretamente com as perguntas do roteiro de entrevista. Nesta etapa, ainda se identificaram os temas recorrentes nas respostas de mais de um entrevistado.

A terceira etapa compreendeu a categorização das unidades de registro, ou seja, as frases com significado próprio cujas temáticas já haviam sido definidas na segunda etapa. Desta forma, as unidades de registro dos diferentes sujeitos entrevistados foram agrupadas em 
categorias pertencentes às mesmas perguntas, de modo a inventariar o conteúdo analisado. Neste passo do processo, explicitou-se a concordância ou discordância de entrevistados bem como a convergência ou divergência da literatura revisada.

Segundo Bardin (2016, p. 149) a categorização pode empregar dois processos inversos:

- é fornecido o sistema de categorias e repartem-se da melhor maneira possível os elementos à medida que vão sendo encontrados. Este é o procedimento "por caixas" de que já falamos, aplicável no caso de a organização do material decorrer diretamente dos funcionamentos teóricos hipotéticos;

ou

- o sistema categorias não é fornecido, antes resulta da classificação analógica e progressiva dos elementos. Este é o procedimento por "acervo". O título conceitual de cada categoria somente é definido no final da operação (BARDIN, 2016, p. 149).

Portanto, considerando a natureza exploratória desta pesquisa, optou-se por utilizar o segundo processo de categorização conforme Bardin (2016), de modo que as categorias foram definidas no decorrer da análise de conteúdo. O processo de categorização durante a análise produziu o conjunto categorial representado a seguir:

A - Interesse pelo PBL

1. Evolução do uso de outras metodologias ativas

2. Exposição a pessoas que já experienciaram o uso de PBL

3. Formação acadêmica em licenciatura e pós-graduação stricto sensu

4. Pré-requisito da instituição de ensino empregadora

B - Uso em Contabilidade

1. Contextualizar o ensino com ambiente de mercado de trabalho

2. Desenvolvimento de habilidades pessoais/soft skills

C - Dificuldades de implementação

1. Experiência didática anterior discente

2. Experiência profissional anterior discente
3. Esforço de ensinar método e conteúdo concomitantemente

4. Infraestrutura da universidade

5. Apoio técnico da universidade

6. Perfil imediatista dos discentes

7. Rejeição pessoal discente ao PBL

D - Demandas do docente

1. Volume de trabalho extra

2. Atualização

3. Perda do poder

E - Adequação ao grau de especialização do conteúdo

1. Customização do assunto

2. Especificidade do problema

3. Praticidade do conteúdo

4. 'Bagagem' do aluno

F - Adequação à natureza do conteúdo

1. Adequação em ciências humanas

2. Adequação em ciências exatas 
$\mathrm{G}$ - Problemas decorrentes da

Contabilidade

1. Ausência de empecilhos

2. Falta de familiaridade com o PBL

$\mathrm{H}$ - Expectativas de longo prazo para o

PBL

Aos entrevistados foi solicitada a assinatura do Termo de consentimento livre e esclarecido, com a autorização do uso do conteúdo da entrevista após a apresentação do projeto da pesquisa e a explicação do propósito de seu desenvolvimento. Também foi garantido o anonimato do entrevistado, ou seja, os autores garantiam que o conteúdo da entrevista não seria relacionado ao entrevistado, bem como que a identidade do entrevistado não seria revelada no artigo. Quando a entrevista foi realizada, presencialmente, foi pedida a assinatura em via impressa do termo. Aos entrevistados via Skype ${ }^{\circledR}$ foi solicitado que assinassem o termo e mandassem uma via escaneada ou um e-mail resposta em que o texto mostrasse concordância com o conteúdo dos termos.

\section{$4 \quad$ ANÁLISE E DISCUSSÃO DOS RESULTADOS}

A partir das oito questões utilizadas nas seis entrevistas, procedeu-se a análise de conteúdo das respostas dos entrevistados.

\subsection{De onde surgiu o interesse por PBL?}

Neste primeiro momento de análise, buscaram-se identificar quais foram as razões que despertaram o interesse pelo PBL por parte dos seis entrevistados. Foi possível identificar quatro origens distintas: da evolução do uso de metodologias de aprendizagem ativa; do interesse pela experiência de pessoas que utilizaram o PBL; pela formação acadêmica continuada; e como um condicionante para a manutenção do emprego. Descreve-se aqui cada uma dessas experiências iniciais, retomando as falas dos entrevistados.

O interesse por PBL decorreu da evolução do uso de aprendizagens ativas, de modo geral. O Entrevistado 2 passou a adotar o PBL após exaurir o uso das simulações e casos, encontrando no PBL uma alternativa de ensino-aprendizagem ainda baseada em aprendizagem ativa, conforme ilustra o trecho a seguir:

76 CONTEXTUS - Revista Contemporânea de Economia e Gestão. Vol. 17 - № 1 - jan./abr. 2019 
[...] o primeiro é que eu venho usando técnicas que de alguma forma são ativas [...] eu uso casos há muitos anos. Então isso, de alguma forma, já vem caminhando na graduação [...] eu estou cansado de usar simulação e cansado de usar os casos [...] a grande crítica dos alunos é que eles querem uma disciplina prática [...] É uma evolução ao longo do tempo. E são coisas que eu acho que podem ser mais adequadas para [o ensino da] Contabilidade. (Entrevistado 2)

A experiência acumulada pelo Entrevistado 2, que utilizou três métodos de aprendizagens ativas, despertou o interesse do Entrevistado 3, conforme mostra o trecho a seguir:

Da pressão do 'Entrevistado 2'. [...] eu acho que, no nosso departamento, [o Entrevistado 2] é o maior incentivador na questão do PBL. É o único que eu conheço que formalmente utiliza o PBL. [...] Foi basicamente um convite do 'Entrevistado 2' que eu topei na hora. Basicamente aí que surgiu [o interesse]. [Eu] conhecia alguma coisinha, mas, assim, nada profundamente como ele conhece, né. (Entrevistado 3)

Dessa forma, percebe-se a existência de uma influência lateral entre docentes que atuam em um mesmo curso de graduação de uma mesma instituição de ensino. Outra forma de aproximação com o PBL foi a formação acadêmica de graduação, mestrado e doutorado. Essa forma foi exposta pelos entrevistados 4 e 5, que tiveram a oportunidade de conhecer o método ainda durante os ciclos de disciplinas de graduação e pós-graduação, respectivamente, conforme mostram os relatos a seguir:

[...] eu também trilhei um caminho para o lado da licenciatura, que foi por meio do curso de Letras. Então lá eu já tive uma primeira experiência com o método, mas uma experiência [...] teórica. Então, fiquei sabendo que existiam métodos diferentes. [...] (Entrevistada 4)

Eu tenho interesse pela área de educação desde 2006. Durante o mestrado meu interesse já era na área de educação. Na minha dissertação do mestrado, eu já discutia as competências e os atributos dos professores em sala de aula. [...] Durante o doutorado, eu fiz disciplinas lá na [Faculdade de] educação. [...] E, também, a minha tese discute [...] o desafio da formação na pós-modernidade. (Entrevistado 5)

A influência do Entrevistado 2 também foi percebida nas respostas dos Entrevistados 4 e 5, que vivenciaram a divisão de uma disciplina que estava sendo implementada pelo Entrevistado 2 e sobre a qual ambos realizaram pesquisas. O interesse da Entrevistada 6 iniciou após conduzir uma disciplina de metodologia de ensino em um programa de pósgraduação stricto sensu, com dinâmica de seminários, em que uma aluna, oriunda de outra área, fez uma exposição sobre o PBL, como mostra o trecho a seguir.

Eu comecei a dar aula no mestrado junto com o professor [omitido] em 2006, dando a disciplina de metodologia. Depois, na sequência, em 2007, eu fiquei sozinha com a disciplina. E eu trouxe, então, a discussão de métodos de ensino que não fossem os obviamente tradicionais. Era um grupo pequeno de 
alunos e uma das alunas era uma aluna de outro programa que a disciplina era optativa. Ela trouxe, então, o PBL como uma alternativa de método de ensino que estava sendo pesquisado na Engenharia de Produção [...] e eu acabei gostando muito desse método. (Entrevistada 6)

Já a experiência da Entrevistada 1 foi de natureza totalmente diversa dos demais entrevistados, pois, ao contrário deles, cujo interesse partiu de vontade própria, a Entrevistada 1 explicou que o uso de PBL, como metodologia de ensino em sala de aula, era um condicionante para a manutenção do emprego, conforme mostra o trecho a seguir:

I happened to be teaching in a problem-based learning environment. So that was my first introduction to problem-based learning. And as a requirement, before I could teach, I had to go through a mandatory training of how to facilitate in problem-based learning and what is problem-based learning. So, when I got to learn more and more, I became interested. So that's the starting point for me. (Entrevistada 1)

Nesse sentido, os entrevistados elencaram uma dinâmica de influência por parte da formação acadêmica, por parte do ambiente em que atuam e por parte do próprio exercício profissional de atividade docente. Além disso, o Entrevistado 2 se mostrou como um precursor e entusiasta, acompanhando quatro dos demais entrevistados em atividades de docência e pesquisa acerca do PBL.

Por fim, constatou-se a importância de expor docentes dos cursos de Ciências Contábeis às metodologias ativas, como alternativa às aulas expositivas tradicionais, dado que, em sua maioria, são oriundos de cursos de bacharelado, os quais não contemplam o estudo da atividade docente e das metodologias de ensino-aprendizagem, sequer superficialmente, e perpetuam a ausência da formação docente também na pós-graduação (LAFFIN; GOMES, 2016; NGANGA et al., 2016).

\subsection{Por que estudar PBL em Contabilidade?}

A segunda questão realizada na pesquisa teve por objetivo identificar o que fundamenta a opinião dos entrevistados sobre a adequação de se adotar o PBL em disciplinas no curso de graduação de Ciências Contábeis. A primeira das motivações relatadas pelos entrevistados foi a possibilidade de, na tomada de decisão, contextualizar o processo de ensino-aprendizagem com as características do ambiente do mercado de trabalho, como mostra o trecho a seguir: 
[...] Porque envolve uma palavra chamada contexto. Então o que que é interessante para o aluno? É que ele vai estudar aquilo que ele, de alguma forma, vai reconhecer no contexto da vida dele. Da vida profissional ou do estágio ou da gerência. E o PBL permite fazer isso. [...] (Entrevistado 2)

O fator mercado de trabalho, elencado pelo Entrevistado 2, foi recorrente na fala dos entrevistados 1 e 4, conforme observado a seguir:

[...] the outcomes that we want of accountants [...] in the 21st century, is not just to work as a solo accountant; we want them to work in teams, across nations, and we want them to put together different sets of data and analyze. Even in some instances, we want them to be able face situations that they have not experienced before. So complex situations and how to break down and how to work that situation; this kind of training is provided by technology of educational methodology like problem-based learning. (Entrevistada 1)

[...] eu conhecia as ferramentas no curso de Letras, mas eu só lecionei Contabilidade na minha vida. Então, foram entre 8 e 9 anos lecionando diversas disciplinas em Contabilidade [...] porque ela [Contabilidade] trabalha com o mercado de trabalho. [...] trazer esse mercado de trabalho pra dentro da sala de aula é uma coisa, assim, fantástica [...]. (Entrevistada 4)

As entrevistas 1 e 4 indicam a preocupação dos docentes com o caráter/tiver eminentemente prático do ensino de Contabilidade, direcionado para a imersão do estudante no mercado de trabalho (LOBOSCO, 2007; VASCONCELOS et al., 2007). Tal fato vai de encontro às críticas históricas da formação profissional em Contabilidade, que acusam o curso de ignorar as práticas de mercado (MACHADO, 1982; CARVALHO; NAKAGAWA, 2005). O desenvolvimento de habilidades pessoais e profissionais demandadas dos contadores, segundo Ribeiro Filho et al. (2006) e Oliveira et al. (2016), é outra das vantagens derivadas da adoção do PBL nos cursos de Ciências Contábeis, conforme o relato do Entrevistado 5:

Eu entendo que o PBL é muito importante pelo aspecto de questionamento, da visão problematizadora que ele tem na sua estrutura, na forma de você levantar um problema, uma questão da realidade e buscar uma fundamentação teórica, uma estruturação e consolidar isso no relatório científico. Todos os momentos, também, que o PBL possibilita de socialização do conhecimento que foi produzido, que vai sendo construído [...] dinâmica de ensino-aprendizagem na área de negócios que requer a formação de habilidades de liderança, de comunicação, de escrita. Eu acho que o PBL, ele se encaixa muito bem. Na minha percepção. (Entrevistado 5)

Mediante o exposto, conclui-se que as razões que levaram os entrevistados a decidirem pela adoção do PBL em cursos de Ciências Contábeis direcionavam-se pelo mercado de trabalho, tanto no sentido de simular as condições do ambiente de trabalho, ou seja, o ambiente da empresa, como também o desenvolvimento de soft skills demandados pelas empresas, conforme Siqueira et al. (2009), Lehmann (2010), Stanley e Marsden (2012; 2013). 
E mais, os entrevistados indicam que o PBL é uma opção estratégica para os cursos de Ciências Contábeis responderem à crítica de que a formação do profissional contábil está desalinhada das práticas de mercado, embora, nesse sentido, outras metodologias de ensinoaprendizagem ativas, como simulação e casos citados pelo Entrevistado 2, poderiam suprir tal demanda de forma equivalente.

\subsection{Quais as maiores dificuldades de implementação (dos alunos, da instituição)?}

No desenvolvimento da pesquisa, buscou-se, também, identificar as dificuldades encontradas pelos entrevistados com a implantação do PBL. Nesse sentido, uma das dificuldades apresentadas foi o fato de que os alunos são oriundos de uma formação acadêmica fortemente baseada em metodologias tradicionais de ensino, tanto anteriormente ao ingresso na graduação, quanto nos primeiros anos do bacharelado, principalmente baseada em aulas expositivas e expositivo-dialogadas. Essa experiência anterior constitui um fator dificultador, conforme confirmam os relatos a seguir:

Porque nós temos uma cultura tradicional. Então, a gente está com um aluno, que está ingressando no curso de contábeis, que durante 12 anos da vida dele estudou no ensino tradicional. Como que agora você vai querer colocar o PBL na cabeça dele? Não dá! Ele está acostumado a ficar sentadinho ali, ouvindo bronca, porque ele está conversando com um colega e ele não lê o material. Ele está ali, porque ele quer absorver conhecimento. Então, esse vai ser um paradigma que, no início, pra quem quer começar com PBL, já vai saber que vai encontrar e vai ter/tiver que lidar com isso. (Entrevistada 4)

[...] então, não é fácil esse processo de trazer esse aluno de uma metodologia estruturada, como aula expositiva, para uma metodologia menos estruturada, como o PBL, e saber exatamente em que ponto fazer a intervenção [...] eu percebi que faltou o conhecimento dos professores nesse sentido. (Entrevistado 5)

Esses achados vão ao encontro da pesquisa de Krüger e Ensslin (2013), que já alertavam para a maior receptividade ou familiaridade dos alunos de Contabilidade brasileiros com metodologias tradicionais, principalmente as aulas expositivas (SOARES; ARAÚJO, 2008). A experiência anterior, relatada pelos Entrevistados 4 e 5, da exposição dos estudantes apenas a aulas expositivas, ao longo do ensino fundamental e médio, na verdade, também é compartilhada pelos professores em sua formação acadêmica, intensificando a dificuldade de inserir o estudante em um ambiente dinâmico de aprendizagem, o qual também não foi vivenciado pelos docentes. 
Além disso, a necessidade de mostrar como funciona o método de PBL, juntamente com a necessidade de desenvolver os conteúdos listados na ementa da disciplina, constitui um desafio de distribuição do tempo de duração, como registrou o Entrevistado 3:

[...] um problema é que os alunos não conhecem o PBL. Então, você leva um tempo danado para tentar fazer com que eles entendam [a dinâmica do método]. E eu não sei se um semestre é tempo suficiente pra isso, numa disciplina como era a nossa, de dois créditos. [...] eu acho que se a gente viesse desde o primeiro ano com experiências usando PBL, ela teria sido mais fácil. (Entrevistado 3)

O conjunto de experiências anteriores do estudante com metodologias de ensino tradicionais soma-se ao conjunto de experiências profissionais desse mesmo estudante, quando se considera a dificuldade na receptividade ao PBL:

[...] estar numa sala de aula em que $100 \%$ dos alunos estão no mercado de trabalho é diferente de você trabalhar numa sala de aula em que os alunos estão ingressando na universidade, e que muitos ainda não possuem nem estágio. (Entrevistada 4)

[...] quando você pega um aluno no fim do curso como eu pego, ele já está moldado. (Entrevistado 2)

O elemento da experiência profissional do aluno, anterior à disciplina com o uso desse método, é um fator crítico, à medida que o PBL pretende proporcionar a vivência de um ambiente dinâmico, que simula o ambiente profissional e suas demandas. A experiência do PBL para um aluno que já vivenciou o ambiente de trabalho, com todas as demandas e responsabilidades, é muito diferente daquela vivenciada por um aluno que, em nenhum momento, sequer estagiou.

Para além da experiência prévia dos alunos, a qual se mostrou um fator recorrente nas falas dos entrevistados, também se percebeu a questão da estrutura disponibilizada pela universidade para a oferta de disciplina, tanto no que toca ao espaço físico, quanto ao apoio técnico-pedagógico. As falas, a seguir, ilustram essas demandas:

Em minha opinião, a maior dificuldade é o espaço físico que a gente tem. [...] Hoje em dia, eu tenho uma turma de Contabilidade Empresarial com 65 alunos, numa sala de aula que comporta 60,70 alunos. O espaço não dá para trabalhar em grupo. (Entrevistada 6)

[...] um professor só em sala de aula, ele dá conta? Ah, ele precisa de monitores. Precisa de estagiários. Como que ele vai se organizar? Claro que o primeiro ano vai ser difícil, mas, depois, ele vai se adaptando, ele vai se ajustando. (Entrevistada 4)

A solução para essas duas demandas, por parte da instituição de ensino, apresenta características bastante distintas, como problemas de gestão: enquanto a contratação e designação de monitores que auxiliem os docentes na condução da disciplina é uma atividade que demanda, usualmente, pouco tempo dentro da estrutura universitária; a adaptação do espaço físico se constitui um desafio maior, pois exige planejamento prévio, incluindo até 
aquisição de mobiliário e reforma de salas de aula. A necessidade da contratação de monitores para auxílio dos professores já era prevista pela pesquisa de Johnstone e Biggs (1998).

Por outro lado, enquanto a reforma de uma sala de aula, adaptadando-a para utilização do PBL, é uma solução permanente; enquanto a contratação de monitores é uma atividade periódica, a ser repetida, semestralmente, a cada oferta da disciplina, que pode oscilar conforme a disponibilidade orçamentária da instituição.

Foram, ainda, referidos outros elementos que expressam dificuldades encontradas por parte dos entrevistados, mas de forma menos regular que os anteriormente apresentados. Um deles foi a característica imediatista da geração atual de estudantes de graduação. Segundo a Entrevistada 6, os alunos de graduação pertencem a uma geração com foco imediatista da informação e com pouco interesse no processo de aprendizagem e de investigação. Isso é corroborado com Krüger e Ensslin (2013), que reforçam que os alunos atuais, ao se depararem com uma dúvida sobre o conteúdo ou sobre um exercício realizado, preferem questionar alguém que possa dar a resposta do que proceder a uma busca por conta própria.

A Entrevistada 6 alerta, também, que, eventualmente, há uma acentuada rejeição ao método PBL por parte de um ou outro aluno em cada turma, mas que, numericamente, é uma proporção insignificante e que, usualmente, o aluno acaba por se adaptar ao método no decorrer da disciplina. A mesma Entrevistada ressalta que, eventualmente, ao final de alguma discussão de algum ponto da ementa, ela necessita intervir com a utilização de slides, numa perspectiva de aula tradicional, para complementar ou aprofundar a discussão quando ela se apresenta superficial.

Nesse sentido, concordando com o estudo de Rodrigues e Araújo (2007), as entrevistas apontam que as dificuldades de implementação do método PBL são categorizadas: em uma dimensão de experiência prévia dos estudantes (acadêmica e profissional); numa dimensão institucional (estrutura física e apoio técnico-pedagógico); e em questões comportamentais pontuais dos estudantes.

\subsection{Do ponto de vista do professor, quais são as principais demandas para quem adota o PBL?}

Buscou-se, então, um aprofundamento na compreensão das demandas da implementação do PBL, agora concentrado, principalmente, segundo a perspectiva do docente. Assim, foi possível identificar uma dimensão relacionada ao volume de trabalho, demandado pelo docente. $\mathrm{O}$ acréscimo do volume de trabalho foi relatado pelos entrevistados, 
ocorrer tanto dentro quanto fora da sala de aula. Os relatos a seguir demonstram esse contexto dentro da sala de aula:

[...] é uma disciplina que o operacional dela é bastante árduo. Assim, a gente teve que trabalhar muito. Por quê? Porque ela demanda muita atividade. Porque o foco é no aluno. Então, tem muita entrega do aluno. Tem muito feedback do professor. [...] para umas aulas a gente tinha que preparar material e, em outras disciplinas, que você já ministra há muito tempo, você não vai criar nada de novo. Você vai trabalhar em cima [do material que já tem]. Então, acho que é um pouco mais fácil. (Entrevistado 3)

[...] meu trabalho é muito maior ao trabalhar com PBL do que não trabalhar com o PBL, ou seja, no método tradicional. (Entrevistada 6)

A Entrevistada 4, por sua vez, expõe o aumento do volume de trabalho em relação à adoção de metodologias tradicionais, fora da sala de aula:

Se as instituições são tradicionais, elas têm estruturas tradicionais. Para um professor que inicia o PBL hoje, se ele ganha por hora-aula, ele já tem que ter/tiver consciência que vai ter/tiver quatro, cinco vezes mais trabalho fora de sala de aula do que se ele for lá e der uma aula tradicional. E, talvez, como ele já tem a matéria preparada de anos antes [...] ele vai lá, deu a aula dele, ganhou o dinheiro dele e está satisfeito. Agora, se isso bastar, o tradicional bastou. Então, ele não vai aplicar o PBL. (Entrevistada 4)

Fora da sala de aula há, ainda, a demanda por atualização, expressa na fala da Entrevistada 6, que acredita se tratar da maior demanda do docente:

Eu acho que é o estudo permanente [...] Porque eu nunca estudei tanto quanto eu estudo pra trabalhar com PBL $[\ldots]$ a demanda é muito maior para pesquisa. A demanda para estar atualizada. A demanda para estar muito firme nas minhas posições. (Entrevistada 6)

Para além do elemento volume de trabalho, que foi bastante recorrente e enfatizado nas falas dos entrevistados, foi citado o fator perda do poder por parte do professor ao adotar a metodologia do PBL. Ou seja, o professor não ocupa mais a centralidade do papel de ensinoaprendizagem, na fala da Entrevistada 4:

[...] o poder, como é que fica? Eu vou abrir mão do meu poder? Eu, deixar o aluno como ativo significa que já não tenho mais aquele autoritarismo. Será que eu sei como trabalhar em grupo? Será que eu sei lidar com um grupo? Porque os professores também se formaram no [ensino] tradicional e ensinam [de modo] o tradicional e até hoje deu certo. Então, por que nós vamos mudar agora? (Entrevistada 4)

As demandas dos docentes, quando da adoção do PBL, podem ser categorizadas em: volume de trabalho; e relações de poder. Enquanto a primeira categoria engloba um perceptível aumento da carga de trabalho fora da sala de aula; a segunda engloba a tensão do professor, que deixa de ser figura central no processo de ensino-aprendizagem. A questão do aumento do volume de trabalho se torna crítica quando analisada à luz da conjuntura política e do visível processo de precarização do ensino, vivenciada em anos recentes, tanto no âmbito das universidades públicas quanto no ensino superior privado. 
A remuneração representa um aspecto fundamental para o professor do ensino privado, pois se relaciona, também, a reconhecimento e valorização profissionais. Além disso ou mais que isso, ela representa a garantia de condições de trabalho e carreira justas, dignas e atrativas aos profissionais da educação (PICOLLI, 2017). Ao adotar uma metodologia de ensino que aumente a carga de trabalho fora da sala de aula, o docente, na iniciativa privada, opta por não ministrar outras aulas, o que impacta, diretamente, em sua remuneração e, consequentemente, em sua qualidade de vida. Já, no ensino superior público, no qual os professores são, em geral, contratados em regime de dedicação exclusiva, a adoção de metodologia que aumenta a carga de trabalho fora da sala de aula afeta o desempenho no desenvolvimento das atividades de pesquisa e extensão, tornando as condições de trabalho ainda mais precárias (BOSI, 2007; GUIMARÃES; SOARES; CASAGRANDE, 2012).

\subsection{O PBL é mais adequado a conteúdos genéricos ou especializados?}

A seguir questionou-se a percepção dos entrevistados acerca do quão adequada é a adoção do PBL a conteúdos genéricos ou conteúdos especializados, no curso de graduação em Contabilidade. A Resolução CNE/CES nº 10, de 16 de dezembro de 2004 (BRASIL, 2004) regulamenta os cursos de bacharelado em Ciências Contábeis, orientando que devem contemplar conteúdos de formação básica, como Administração, Economia, Direito, Métodos Quantitativos, Matemática e Estatística; e de formação profissional, como Contabilidade financeira, Contabilidade governamental, Auditoria, Perícia e Controladoria. Além disso, há a proposição de que os cursos de bacharelado em Ciências Contábeis englobem uma formação generalista, segundo a composição curricular (CAPACCHI et al., 2007; GALDINO; SOARES, 2013; SOARES et al., 2012).

As entrevistas realizadas permitiram a identificação de dois posicionamentos distintos: o majoritário, afirmando que o PBL está adequado a ambos os tipos de conteúdo; e uma exceção, segundo a qual PBL está mais adequado ao ensino de conteúdos específicos.

O Entrevistado 2 indica que o fator-chave para a adoção bem-sucedida do método PBL, independentemente do conteúdo, é a customização do assunto a ser tratado, como demonstra a resposta a seguir:

[...] Mas qual é a questão [de sucesso da adoção]? [...] é a customização da disciplina para a área. Ela tem de ser feita por alguém que entenda da área [...] Você tem possibilidades. Só que a minha impressão, até por cacoete, é que as disciplinas de gerencial são mais fáceis, porque você consegue customizar mais as questões. (Entrevistado 2) 
Nesse sentido, a Entrevistada 4 acresce que o sucesso da adoção do PBL depende da especificidade do problema que se pretende abordar em sala de aula e do nível de complexidade correspondente.

Eu vejo que nos dois é possível trabalhar PBL, um com grau mais simplificado e o outro com grau mais avançado. Nesse sentido, ou seja, se eu quero algo mais específico do aluno, então, eu vou fazer um problema, vou trabalhar com um problema acadêmico de PBL. (Entrevistada 4)

Já o Entrevistado 3 comenta que o PBL não se apresenta mais adequado a conteúdos por serem genéricos ou específicos, mas, sim, pelo grau de praticidade do conteúdo trabalhado.

[...] eu acho que o PBL tem totalmente a ver com disciplinas práticas [...] Todas as minhas aulas têm exercícios, tem cálculos. [...] Então, é uma disciplina que, tranquilamente, cabe o PBL. (Entrevistado 3)

A Entrevistada 6, por sua vez, opina que o fator-chave para o sucesso da adoção do PBL está relacionado ao volume de conhecimentos e experiências acumulados pelos alunos, que ela denomina 'bagagem', conforme os seguintes relatos:

Eu acho que o PBL se adequa para os dois [conteúdos de formação geral e específica]. [...] Porém, eu vejo que, para conteúdos genéricos, o aluno tem que ter/tiver uma bagagem melhor de conhecimentos. (Entrevistada 6)

Em contraposição aos posicionamentos anteriores, que se mostraram recorrentes, o Entrevistado 5 é de opinião que o PBL é adequado mais aos conteúdos específicos, conforme o trecho a seguir:

Eu entendo que o PBL seja mais adequado em conteúdos específicos. Pelo que eu fiz de leitura [...] foi em situações específicas. Mesmo que existam instituições com cursos, com programas estruturados pelo método PBL. [...] Eu percebo que, em cursos específicos, o PBL se encaixa bem. (Entrevistado 5)

A partir das falas dos entrevistados, percebe-se uma opinião predominante de que a adoção do PBL pode ser bem sucedida, independentemente de se tratar de conteúdos genéricos ou específicos, contanto que o docente atente para a necessária customização do método ao conteúdo, à especificidade do problema desenvolvido, à relação do problema com a prática contábil e ao background dos alunos, divergindo da pesquisa de Siqueira et al. (2009), a qual afirma que a adoção do PBL pode não ser adequada a todas as disciplinas.

Já a contraposição feita pelo Entrevistado 5, de que o PBL é mais adequado a conteúdos específicos, pode ser interpretada como uma variação da condição de especificidade dos problemas, antes elencada pela Entrevistada 4. Embora o Entrevistado 5 se utilize dessa característica para interpretar a adoção restrita do PBL; a Entrevista 4 se utiliza da mesma característica para justificar que o PBL é adequado em ambos os tipos de conteúdos. 


\subsection{O PBL é mais adequado a ciências humanas ou exatas?}

Siqueira et al. (2009) desenvolveram sua pesquisa com o mote de identificar o que os médicos podem ensinar aos contadores, partindo da premissa de que o PBL surgiu, inicialmente, da área da medicina. Ou seja, queriam investigar o quanto uma técnica criada na área de ciências da saúde pode contribuir na área de ciências sociais aplicadas. E assim, nesse sentido, a questão ora abordada surgiu com o intuito de analisar o quanto o PBL, segundo a visão dos entrevistados, é adequado às ciências humanas ou exatas.

Com relação aos especialistas consultados, percebeu-se um movimento de defesa da adoção do PBL em conteúdo de ciências humanas de forma quase irrestrita, como mostram os seguintes trechos das entrevistas:

$\mathrm{Na}$ área de ciências humanas, [de ciências] sociais aplicadas, não tenho nenhuma dúvida que cabe. Que cabe na Administração, que cabe na Contabilidade, que cabe no pessoal da Psicologia, que cabe para o pessoal, provavelmente, da ECA [Escola de Comunicação e Artes]. (Entrevistado 3)

[...] eu não vejo como mais adequação ao método, eu vejo que a nossa área, por ser uma ciência social, ela está bastante adequada. (Entrevistado 5)

Olha, eu não sei te responder sobre exatas. Eu acho que humanas funciona bem. (Entrevistada 6)

Os entrevistados, em seus depoimentos, demonstraram que o processo de adoção do PBL, no ensino de ciências humanas, se mostra bastante adequado, inclusive sem indicar condicionantes, o que não ocorre em relação às duas opiniões acerca da adoção do PBL em conteúdo de ciências exatas, como evidenciado a seguir:

[...] Quando você dá um curso como aplicação de matemática financeira, eu tenho certeza que pode usar o PBL. [...] Se você me falar que a disciplina de matemática financeira é só para ensinar fórmula, eu não consigo perceber o PBL. Agora, a hora que você disser que eu quero enxergar problemas em que a matemática financeira possa colaborar, eu não tenho dúvida, que dá para pensar neles [como PBL]. (Entrevistado 2)

A questão é identificar um problema real que possa ser abordado [...] as aulas de matemática que a gente recebe no nosso curso são dadas pelo IME [Instituto de Matemática e Estatística] e, muitas vezes, o professor que vem do IME dar aula aqui, dá a mesma aula aqui que em todas as outras unidades da USP, porque é a mesma disciplina de Cálculo 1. Quase todo curso tem Cálculo 1 e o professor dá a mesma coisa. Ele não consegue fazer a aplicação para nossa área de estudo. O que a gente poderia ter/tiver um caminho diferente é se a FEA [Faculdade de Economia, Administração e Contabilidade], enquanto unidade, tivesse um grupo de professores de matemática para dar aula de matemática nos cursos de negócios da FEA. (Entrevistado 3)

O Entrevistado 3 propõe que a existência de um conjunto de docentes, que adaptasse e ministrasse as disciplinas de exatas para os cursos de negócios da FEA, seria uma alternativa 
que possibilitaria maior adoção do PBL. A opinião do entrevistado é de que a disciplina de Cálculo 1 é estruturada de forma genérica demais, de modo a ser ministrada, igualmente, em diversos cursos da universidade.

A Entrevistada 4 analisa a adoção do PBL para conteúdo de ciências humanas ou exatas sob uma ótica de formação acadêmica, que crie um profissional apto a suprir as demandas da sociedade, como mostra o trecho a seguir:

Eu vejo assim: nas duas é possível! Porque, qual que é a proposta da universidade? Das faculdades? Dos cursos? Indiferente do curso que seja, é formar uma pessoa para desenvolver aquela habilidade profissional, atendendo a sociedade, seja na área da matemática, da física, na medicina, da contabilidade, da engenharia ou, até mesmo, nas licenciaturas. A proposta é essa. (Entrevistada 4)

O depoimento da Entrevistada 4 retoma das grandes vantagens atribuídas ao método PBL, que é propiciar ao estudante da área de negócios a vivência de problemas práticos da realidade organizacional. A utilização do PBL por docentes de humanas ou exatas pode sofrer influência da própria exposição dos docentes às diferentes técnicas de ensino-aprendizagem, durante o seu percurso formativo, porque, aparentemente, a formação em humanas, no Brasil, expõe aos alunos uma variedade maior de metodologias de ensino do que a formação em exatas.

\subsection{Houve problemas específicos na aplicação do PBL em Contabilidade?}

Procurou-se, ainda, compreender os empecilhos enfrentados na adoção do PBL, que fossem decorrentes, especificamente, do curso de Contabilidade. No entanto, o que mais se observou no conjunto de respostas dos entrevistados, foi a ausência de tais empecilhos. Os entrevistados afirmaram não terem encontrado dificuldades inerentes ao curso de Ciências Contábeis.

Porém, algumas respostas indicaram a existência de dificuldades ocorridas na implantação do PBL, como relatado a seguir:

Uma das limitações que a gente teve disciplina [é que] o aluno não está acostumado a assumir a responsabilidade. Ele não está muito acostumado a pensar. O nosso aluno, ele não está muito acostumado a entender que o foco é ele. [...] o nosso aluno não tem esse perfil de que ele é um centro e, na verdade, ele não está errado nisso, porque o nosso projeto político-pedagógico não previa isto. $\mathrm{O}$ nosso histórico não previa isso. E, aí, eu estou falando de educação brasileira como um todo. (Entrevistado 3)

O aluno tem característica de buscar uma certeza do conhecimento. Ele quer a resposta exata. Ele foge de ambiguidades e de complexidades. Então, eu entendo que nosso aluno tem essa característica de resistência um pouco maior. (Entrevistado 5) 
Tanto o Entrevistado 3 quanto o Entrevistado 5 identificaram dificuldades na aplicação do PBL em Ciências Contábeis, mas não derivadas do curso ou de conteúdos específicos, e sim do perfil dos alunos que frequentam o curso, extrapolando para a educação no país. A falta de familiaridade do aluno com uma metodologia em que ele se encontra no centro do processo de ensino-aprendizagem e a característica do aluno de demandar respostas rápidas foram apontadas, por parte dos entrevistados, como dificuldades para aplicação do método. No entanto, não se pode afirmar que tais características sejam idiossincrasias exclusivas dos estudantes de Ciências Contábeis, mas, sim, características da geração dos jovens adultos que estão ingressando no ensino superior ou resultado de um trajeto formativo, calcado em metodologias tradicionais de ensino.

A Entrevistada 6 acredita não ter/tiver tido problemas com a aplicação do PBL em Contabilidade devido ao seu esforço de fazer compreender o funcionamento e o objetivo do método desde o início de sua adoção, como mostra o excerto de seu relato:

Não tem problema nenhum, porque isso fica muito claro no objetivo da disciplina. [...] Se eu tenho uma disciplina muito bem encadeada dentro do projeto político-pedagógico, acabou isso. O método é uma consequência e os alunos gostam muito. (Entrevistada 6)

Nota-se, ainda, que o projeto político-pedagógico foi um elemento recorrente nas falas dos Entrevistados 3 e 6. O Entrevistado 3 afirmou que houve dificuldades na aplicação do PBL, pois a metodologia não estava de acordo com o projeto político-pedagógico da instituição. Para a Entrevistada 6, não houve dificuldade na aplicação do PBL, justamente por ele estar alinhado com o projeto político-pedagógico do curso. Inclusive, a visão da Entrevistada 6 de que os alunos recebem bem a adoção do PBL converge para os achados de Cottell (2010), Dee e Durtschi (2010) e Lehmann (2010). Esses relatos trazem a compreensão da relevância de fatores institucionais como alavancadores ou atravancadores do processo de implementação. Na falta do apoio da instituição, fica a possibilidade de compartilhamento da experiência e da influência de colegas, em um efeito de contágio.

\subsection{Qual é a sua expectativa no longo prazo? (Em termos de PBL em Contabilidade)}

A última das questões realizadas durante a entrevista foi estabelecida com o objetivo de identificar a percepção dos entrevistados acerca das tendências futuras. A pergunta, que nas duas primeiras entrevistas era 'qual é a sua expectativa no longo prazo', foi reescrita para 'qual é a sua expectativa no curto e longo prazo', no caso das últimas quatro entrevistas. Os entrevistados possuem visões opostas sobre o atual estágio de adoção do PBL e a tendência de 
curto prazo. Enquanto os Entrevistados 2 e 3 veem a adoção como incipiente, as Entrevistadas 4 e 6 possuem percepções mais favoráveis ao grau de adoção, como mostram os trechos dos relatos reproduzidos a seguir:

[...] eu não enxergo grandes crescimentos rápidos. [...] Isso é trabalho complicado. (Entrevistado 2)

[...] é uma pergunta muito difícil, porque ele [PBL] não está na ordem do dia [...] (Entrevistado 3)

[...] nesse curto prazo, está indo bem rápido. Então, eu vejo que há uma tendência dele [PBL] ser mais incorporado na área de contabilidade, sim. (Entrevistada 4)

A curto prazo, eu acho que já é realidade. Vários professores trabalham. (Entrevistada 4)

As causas apontadas como justificativas para as percepções são distintas. O Entrevistado 2 acredita que as dificuldades para o crescimento da adoção do PBL derivam do volume de trabalho por parte do docente, da receptividade por parte dos estudantes, do posicionamento da instituição e da capacidade do docente de encontrar aliados, que cultivem a mesma compreensão e tenham disposição em adotar o método, como fica demonstrado no relato a seguir:

Principalmente, porque toma tempo. [...] Você não vai ter/tiver uma classe te aplaudindo de pé. Dizendo que foi a maior coisa da vida deles [...] Eu fiz a disciplina, mandei para o conselho e a postura do departamento foi de não boicotar. Mas, o que acontece, é que quando você tem iniciativa individualmente, a institucionalização é mais complicada, porque você tem de ganhar na conversa e encontrar pessoas que queiram [adotar] e que busquem a disciplina deste tipo. [...] Porque o segredo da história é ter/tiver colegas que queiram fazer isso. (Entrevistado 2)

[...] na nossa área, talvez seja um pouco mais difícil, porque o grupo de resistência, o grupo que prefere um método estruturado, é muito maior. Então, eu acredito que seja possível surgir pequenos grupos que trabalham nessa estratégia de ensino com resultados muito positivos. (Entrevistado 5)

A fala do Entrevistado 2 vai ao encontro do que pensa o Entrevistado 5, no que tange às parcerias como estratégia para promoção da adoção do PBL em maior escala. Já o Entrevistado 3, que compartilha da visão do Entrevistado 2 sobre o desempenho do PBL no curto prazo, é de opinião que a adoção do PBL é um esforço muito individual e que encontra um concorrente muito forte no uso de métodos tradicionais de ensino, conforme o relato a seguir:

[...] no ano passado a gente fez uma sessão de entrevistas da coordenação com cada um dos professores do departamento. A gente queria ouvir os professores, e o que que apareceu, claramente, é que a principal estratégia de ensino utilizada pelos professores é a aula expositiva e o principal instrumento de avaliação é a prova. Eu vejo que o PBL ainda é um esforço muito individual do Entrevistado 2. [...] ele não está nos planos, nem estratégicos de longo prazo, nem nos planos de curto prazo. (Entrevistado 3)

A Entrevistada 4, que possui uma visão mais otimista sobre o desempenho do PBL no curto prazo, acredita que a adoção o PBL pode ser uma tendência apoiada, principalmente, pelos docentes mais jovens, no que é acompanhada pela percepção do Entrevistado 3. Ela 
acrescenta, também, que, no médio prazo, a oferta de cursos de formação para os docentes mais antigos e o desempenho dos programas de pós-graduação na formação de novos docentes podem constituir uma estratégia para aumentar a adoção do PBL, como mostrado nos relatos a seguir:

Eu vejo que está sendo mais incorporado pelos professores novos. (Entrevistada 4)

[...] a gente tem um ponto positivo que é uma nova geração de professores, tanto de idade quanto de tempo de casa [...] (Entrevistado 3)

[...] No médio e no longo prazo, o que ajudaria os professores que já estão na docência, seriam mais cursos de formação docente, para que eles aprendam essas tecnologias, essas novas abordagens metodológicas ativas. (Entrevistada 4)

[...] o papel dos cursos de pós-graduação na disseminação das metodologias ativas, no caso PBL, é algo crítico para que ele tenha sucesso em longo prazo. (Entrevistada 4)

A Entrevistada 6, que compartilha da visão otimista da Entrevistada 4 em relação ao atual estágio de adoção do PBL, ressalva que o PBL é apenas uma das várias opções de metodologias de aprendizagem ativas que vão se popularizar com o decorrer do tempo:

Em longo prazo, eu acho que o PBL é uma das alternativas. Repito: não é a única. Tenho trabalhado em outros métodos. Estudo de caso, por si só, pra turmas mais maduras, também funciona muito bem. Seminários, que envolvem pessoal com turma mais de final de curso, também funcionam bem. A gente tem uma técnica que eu estou gostando muito de utilizar que é o grupo de verbalização e grupo de observação, que também funciona bem com turmas menores. Então, o PBL é apenas uma das opções. (Entrevistada 6)

Observa-se que os entrevistados não têm uma visão convergente sobre as tendências de adoção do PBL no curto e longo prazos. Porém, a questão permitiu compreender algumas estratégias, que, acreditam os entrevistados, podem auxiliar na promoção do uso do PBL, tais como: a exposição de alunos de programas de pós-graduação a metodologias ativas; a oferta de cursos de atualização didática para docentes com mais anos de docência; e o estabelecimento de grupos de docentes que compartilhem experiências. A visão da Entrevistada 6 de que o PBL é um complemento ao uso de outras metodologias também é compartilhada por Benjamim Jr. (2011). Finalmente, ressalta-se a importância do apoio institucional e da existência de pioneiros, que ousem, e que compartilhem a sua experiência de modo ativo, como ativa é, também, a metodologia de ensino. Afinal, quem quer problemas? 


\section{CONCLUSÃO}

Esta pesquisa teve como objetivo compreender as dificuldades e vantagens encontradas pelos docentes dos cursos de graduação em Contabilidade, que vivenciaram a adoção do PBL em sala de aula. Para tanto, foram realizadas entrevistas com seis docentes de graduação e/ou pós-graduação, apontando que sua formação acadêmica de graduação, nas áreas de Administração e Ciências Contábeis, não proporcionou o contato com o PBL, tampouco com quaisquer outras metodologias ativas.

Dentre as razões relatadas para a adoção do PBL, está a necessidade de proporcionar aos estudantes a atuação em um ambiente que simula o ambiente de trabalho, bem como o desenvolvimento de soft skills, a exemplo da habilidade de trabalhar em equipe e a responsabilidade por partes de processos. Os entrevistados, embora ressalvem que outras metodologias ativas, como simulação empresarial e casos de estudo, sirvam igualmente a este propósito, argumentaram que o PBL é uma estratégia para facilitar à academia responder à crítica de que os cursos de Ciências Contábeis estão desalinhados com as demandas do mercado de trabalho.

As dificuldades elencadas durante a adoção do PBL têm duas origens principais: o background dos estudantes e a estrutura institucional. $\mathrm{O}$ fato de os estudantes terem tido uma formação no ensino fundamental e médio, quase exclusivamente, calcada nas aulas expositivas e expositivo-dialogadas, tão somente com o apoio de quadro e giz, constitui-lhes uma barreira à aceitação de metodologias ativas, que os colocam no centro do processo de ensino e aprendizagem, tirando-os, portanto, de sua zona de conforto. Os fatores institucionais vão desde a estrutura física e o mobiliário das salas de aula, não adequadas para atividades em grupo, até o volume de horas de trabalho demandado na preparação das aulas por parte do docente, sem o acréscimo proporcional na remuneração.

Os entrevistados são de opinião de que não há, a priori, uma adequação maior do uso do PBL a conteúdos genéricos ou especializados, tampouco a conteúdos de exatas ou de humanas. No entanto, há o alerta de que a condição para a adequação do PBL a qualquer conteúdo passa pela necessidade de delinear, cuidadosamente, o problema e especificar, detalhamente, o contexto. Já as perspectivas de uso do PBL, no médio e no longo prazo, divergiram entre os entrevistados: alguns acreditam que a adoção será tímida e demorada, enquanto outras acreditam nele como tendência irrefreável.

As conclusões desta pesquisa podem trazer implicações para a prática docente e a oferta de ensino superior de Ciências Contábeis por instituições de ensino. Do ponto de vista 
didático, a adoção do PBL pode promover um aprendizado mais profundo e duradouro junto aos acadêmicos, podendo refletir um melhor desempenho no Enade e maiores taxas de aprovação no Exame de Suficiência do CFC. Ainda do mesmo ponto de vista, desenvolver habilidades pessoais e de relacionamento por parte dos estudantes pode colaborar com sua inserção e permanência no mercado de trabalho. Pelo viés mercadológico, por sua vez, no caso das instituições de ensino superior privadas, os benefícios da utilização do PBL no ensino de Contabilidade podem ser considerados uma vantagem competitiva em relação às concorrentes.

No âmbito da carreira docente, quem opta pela adoção precisa estar ciente dos alertas feitos pelos entrevistados nesta pesquisa de que há um aumento não apenas no volume de horas gastas na preparação das aulas, mas também na necessidade de atualização teórica e pedagógica. A solicitação de infra-estrutura adequada e apoio institucional também são fatores críticos capazes de colaborar para o sucesso ou fracasso.

Quanto às limitações desta pesquisa, derivam-se da própria abordagem escolhida, que privilegia aprofundar a compreensão do assunto não com o tamanho da amostra, mas com a interlocução com especialistas. Os seis sujeitos, escolhidos por sua experiência na adoção do PBL, em cursos de graduação e pós-graduação de Ciências Contábeis, são informantes diferenciados, que puderam compartilhar suas experiências, percepções e perspectivas.

Sugere-se, para trabalhos futuros, que se investigue o problema de pesquisa pelo ponto de vista dos estudantes, a fim de identificar como e se eles percebem benefícios com a adoção do PBL, e se tais benefícios excedem as dificuldades enfrentadas. Sugere-se, também, expandir a investigação para áreas adjacentes, como a Administração, a Economia e a Engenharia de Produção. Sugere-se, ainda, retomar esses questionamentos futuramente com os mesmos entrevistados, acrescidos de mais docentes com o mesmo perfil, para expandir a compreensão da evolução da adoção do PBL em médio e longo prazos, na área.

\section{REFERÊNCIAS}

BACICH, L.; MORAN, J. (Org.). Metodologias ativas para uma educação inovadora: uma abordagem teórico-prática. Porto Alegre: Penso, 2018.

BARDIN, L. Análise de conteúdo. São Paulo: Edições 70, 2016. 
BENJAMIM JR., V. Teoria da complexidade e contabilidade: estudo da utilização da aprendizagem baseada em problemas como abordagem complexa no ensino da contabilidade. 2011. Dissertação (Mestrado em Controladoria e Contabilidade: Contabilidade) - Faculdade de Economia, Administração e Contabilidade, Universidade de São Paulo, São Paulo, 2011.

BOSI, A. P. A precarização do trabalho docente nas instituições de ensino superior do Brasil nesses últimos 25 anos. Educação e Sociedade, Campinas, v. 28, n. 101, p. 1503-1523, dez. 2007.

BRASIL. Resolução $\mathbf{n}^{0}$ CNE/CES 10, de 16 de dezembro de 2004. Institui as Diretrizes Curriculares Nacionais para o Curso de Graduação em Ciências Contábeis, bacharelado, e dá outras providências. Diário Oficial da União, 16 dez. 2004. Conselho Nacional e Educação.

CAPACCHI, M. et al. A prática do ensino contábil no Estado do Rio Grande do Sul: uma análise da grade curricular frente às exigências legais e necessidades acadêmicas. In: CONGRESSO ANPCONT, 1º, 2007, Gramado. Anais... Gramado: Anpcont, 2007.

CARVALHO, A. M. R.; NAKAGAWA, M. Uma proposta de mudança da formação acadêmica do profissional de custos. In: CONGRESSO INTERNACIONAL DE CUSTOS, 9, Florianópolis. Anais... Florianópolis: CIC, 2005.

COTTELL JR, P. G. Shreffler stores accounting issues related to consumer receivables, asset impairment, and discontinued operations: A problem-based learning unfolding problem. Issues in Accounting Education, v. 25, n. 4, p. 775-787, 2010.

DEE, C. C.; DURTSCHI, C. Return of the Tallahassee BeanCounters: A case in forensic accounting. Issues in Accounting Education, v. 25, n. 2, p. 279-321, 2010.

ESCRIVÃO FILHO, E.; RIBEIRO, L. R. C. Inovando no ensino de administração: uma experiência com a aprendizagem baseada em problemas (PBL). Cadernos EBAPE. BR, v. 6, n. Ed. Especial, art. 3, p. 1-9, 2008.

FLICK, Uwe. Introdução à pesquisa qualitativa. 3. ed. Porto Alegre: Artmed, 2009.

FREZATTI, F. et al. Análise do desempenho de alunos na perspectiva do 'CHA' em disciplina utilizando PBL: o que significa a síntese? Revista de Contabilidade e Organizações, v. 10, n. 26, p. 3-19, 2016. 
FREZATTI, F.; SILVA, S. C. Prática versus incerteza: como gerenciar o estudante nessa tensão na implementação de disciplina sob o prisma do método PBL? Revista Universo Contábil, v. 10, n. 1, p. 28-46, 2014.

GALDINO, J. A.; SOARES, S. V. O Aspecto Generalista ou Especialista da Formação em Ciências Contábeis nas Universidades Públicas da Região Norte do Brasil: Uma Análise Curricular. In: ENCONTRO DE ENSINO E PESQUISA EM ADMINISTRAÇÃO E CONTABILIDADE, 4., 2013, Brasília. Anais... Distrito Federal: Anpad, 2013.

GIL, Antonio Carlos. Como elaborar projetos de pesquisa. 5. ed. São Paulo: Atlas, 2016.

GUIMARÃES, V. N.; SOARES, S. V.; CASAGRANDE, M. D. H. Trabalho docente voluntário em uma Universidade Federal: nova modalidade de trabalho precarizado? Educação em revista, Belo Horizonte, v. 28, n. 3, p. 77-101, Set. 2012.

JOHNSTONE, K. M.; BIGGS, S. F. Problem-based learning: introduction, analysis, and accounting curricula implications. Journal of Accounting Education, v. 16, n. 3, p. 407-427, 1998.

KRÜGER, L. M.; ENSSLIN, S. R. Método tradicional e método construtivista de ensino no processo de aprendizagem: uma investigação com os acadêmicos da disciplina Contabilidade III do curso de Ciências Contábeis da Universidade Federal de Santa Catarina. Revista Organizações em Contexto, v. 9, n. 18, p. 219-270, 2013.

LAFFIN, M.; GOMES, S. M. S. Formação do professor de contabilidade: O tema em debate. Education Policy Analysis Archives, v. 24, p. 77-31, 2016.

LEAL, E. A.; MIRANDA, G. J., CASA NOVA, S. P. C. Revolucionando a sala de aula: Como envolver o estudante aplicando as técnicas de metodologias ativas de aprendizagem. São Paulo: Atlas, 2017.

LEHMANN, C. M. Internal controls: A compendium of short cases. Issues in Accounting Education, v. 25, n. 4, p. 741-754, 2010.

LOBOSCO, I. F. Caso-problema no ensino de contabilidade introdutória: um estudo da percepção dos alunos do curso de graduação quanto à sua aplicabilidade no desenvolvimento de competências e habilidades. 2007.186 f. Dissertação (Mestrado em Controladoria e Contabilidade) - FECAP - Faculdade Escola de Comércio Álvares Penteado, São Paulo, 2007. 
MACHADO, N. O Ensino de Contabilidade nos cursos de Ciências Contábeis na Cidade de São Paulo. São Paulo, 1982. Dissertação de Mestrado. Escola de Administração de Empresas de São Paulo, Fundação Getúlio Vargas.

MARION, J. C.; MARION, A. L. C. Metodologias de ensino na área de negócios: para cursos de administração, gestão, contabilidade e MBA. São Paulo: Atlas, 2006.

MARTINS, D. B.; ESPEJO, M. M. D. S. B.; FREZATTI, F. Problem-Based Learning no Ensino de Contabilidade Gerencial: Relato de uma Experiência Brasileira. Revista de Educação e Pesquisa em Contabilidade, v. 9, n. 4, p. 430-452, 2015.

NGANGA, C. S. N. et al. Mestres e Doutores em Contabilidade no Brasil: Uma Análise dos Componentes Pedagógicos de sua Formação Inicial. Revista Electrónica Iberoamericana Sobre Calidad, Eficacia y Cambio en Educación, v. 14, p. 1-17, 2016.

OLIVEIRA, H. M.; ARANTES, F. P.; FREITAG, M. S. B.; ROSSI, R. M.; SILVA, J. O. Aprendizagem e desenvolvimento de competências contábeis. Contabilidade, Gestão e Governança, v. 19, n. 3, p. 376-394, 2016.

PÁDUA JR., F. P. et al. Avaliação da percepção de discentes e docentes sobre novas tecnologias de ensino em cursos de graduação em Administração. Administração: Ensino e Pesquisa, v. 15, n. 2, p. 295-321, 2014.

PELEIAS, I. R. et al. Evolução do ensino da contabilidade no Brasil: uma análise histórica. Revista Contabilidade \& Finanças - USP, v. 18, n. n. spe, p. 19-32, 2007.

PICOLLI, I. R. A. A promoção da qualidade de vida dos professores como diferencial estratégico em uma instituição de ensino fundamental e médio. $2017.148 \mathrm{f}$. Dissertação (Mestrado) - Curso de Mestrado em Administração, Programa de Pós-graduação em Administração, Universidade do Sul de Santa Catarina, Florianópolis, 2017.

RIBEIRO FILHO, J. F. et al. Habilidades de comunicação oral de estudantes de Ciências Contábeis: uma análise baseada em percepções de integrantes de corpo docente, corpo discente e profissionais liberais. BASE - Revista de Administração e Contabilidade da UNISINOS, v. 3, n. 1, p. 24-33, 2006.

RODRIGUES, E. A.; ARAÚJO, A. M. P. O ensino da contabilidade: aplicação do método PBL nas disciplinas de contabilidade em uma Instituição de Ensino Superior particular. Revista de Educação, v. 10, n. 10, 2007. 
SILVA, S. S.; OLIVEIRA, M. A.; MOTTA, G. S. Jogos de empresas e método do caso: contribuições ao processo de ensino e aprendizagem em administração. Administração: Ensino e Pesquisa, v. 14, n. 4, p. 677-705, 2013.

SIQUEIRA, J. R. M. et al. Aprendizagem baseada em problemas: o que os médicos podem ensinar aos contadores. Contabilidade Vista \& Revista, v. 20, n. 3, p. 101-125, 2009.

SOARES, M. A. Aplicação do método de ensino Problem Based Learning (PBL) no curso de Ciências Contábeis: um estudo empírico. 2008. Dissertação (Mestrado em Controladoria e Contabilidade) - Faculdade de Economia, Administração e Contabilidade de Ribeirão Preto, Universidade de São Paulo, Ribeirão Preto, 2008.

SOARES, M. A.; ARAÚJO, A. M. P. Aplicação do Método de Ensino Problem Based Learning (PBL) no Curso de Ciências Contábeis: Um Estudo Empírico. In: CONGRESSO ANPCONT, 2., 2008, Salvador. Anais... Salvador: Anpcont, 2008.

SOARES, S. V. et al. O Currículo dos cursos de Ciências Contábeis das Universidades Federais da Região Sul do Brasil: formação especialista ou generalista? Enfoque Reflexão Contábil, Maringá, v. 31, n. 2, p. 7-21, 2012.

SOARES, S. V. et al. Evolução do currículo de Contabilidade no Brasil desde 1809. Revista Catarinense da Ciência Contábil, v. 10, n. 30, p. 27-42, 2011.

SOUZA, N. R.; VERDINELLI, M. A. Aprendizagem ativa em Administração: um estudo da Aprendizagem Baseada em Problemas (PBL) na graduação. Revista Pretexto, v. 15, n. NE, p. 29-47, 2014.

STANLEY, T.; MARSDEN, S. Accountancy capstone: Enhancing integration and professional identity. Journal of Accounting Education, v. 31, n. 4, p. 363-382, 2013.

STANLEY, T.; MARSDEN, S. Problem-based learning: Does accounting education need it? Journal of Accounting Education, v. 30, n. 3, p. 267-289, 2012.

TAN, O. S. Students' experiences in problem-based learning: three blind mice episode or educational innovation? Innovations in Education and Teaching International, v. 41, n. 2,169-184, 2004.

VASCONCELOS, A. L. F. S. et al. Uma reflexão da aprendizagem cooperativa como estratégia de ensino para a formação dos contadores. Revista de Informação Contábil, v. 2, n. 1, p. 72-83, out. /dez. 2007. 
VENDRAMIN, E. O. et al. O Que Pensam os Professores a Respeito do Problem Based Learning como Estratégia de Ensino na Contabilidade? Revista de Graduação USP, v. 3, n. 2,45-53, 2018. 